\title{
Kidney Cancer pT3a TNM Finding v6
}

National Cancer Institute

\section{Source}

National Cancer Institute. Kidney Cancer pT3a TNM Finding v6. NCI Thesaurus. Code C63567.

Kidney cancer with tumor directly invading the adrenal gland or perirenal and/or renal sinus fat, but not beyond Gerota's fascia. (from AJCC 6th Ed.) 